\title{
Effect of Tidal Fluctuation on the Stability of
}

\section{Estuarine Structures in Sarawak}

\author{
S.R. Kaniraj, L.J. Lee and S.N.L. Taib
}

Universiti Malaysia Sarawak, Sarawak, Malaysia

Date Received: 28 October 2015

Date Published: 30 January 2015

\begin{abstract}
Several incidents of lateral movement and failures of estuarine structures have been reported in Sarawak. These structures located in very soft and deep sedimentary soils are usually supported on pile foundations. There is a 4 to $7 \mathrm{~m}$ daily tidal fluctuation in these locations, the effect of which on the ground and the piles is usually neglected in design. A study has been undertaken to formulate improved approaches for the design of riverine and estuarine structures. The validation of a theoretical model requires data on ground movement and pore water pressure changes due to tidal fluctuation. Accordingly, piezometers and inclinometer casings were installed at the sites of two structures where a bridge and jetty are proposed to be constructed. The inclinometers measure the lateral movement of the river banks and a pile installed in the riverbed. The piezometer and inclinometer readings are being recorded periodically. The paper explains the background of the study, case histories of failures, soil conditions at the two sites, details of instrumentation, results of measurement, and the interpretations.
\end{abstract}

Keywords: inclinometer, piezometer, pile, soft soil, tidal fluctuation

\section{INTRODUCTION}

$\mathrm{T}$ HERE had been several incidents of failures of estuarine structures such as bridges, jetties and wharves in Sarawak. Figure 1 shows two such collapsed structures. More examples are listed in Table 1 [1]-[2]. The estuarine structures are usually supported on pile foundations as the soil profile is generally very soft and deep sedimentary soils. There is also a 4 to $7 \mathrm{~m}$ daily tidal fluctuation in these locations. The failures were attributed to unstable riverbank slopes and the pile foundation not being able to resist the lateral load induced by the soil movement. Lateral movement of soil can also occur due to other reasons such as construction activities at the riverbank, scouring of soil below the structure, dredging of the riverbed in front of the structure and more importantly the effects due to changes in the water level caused by tidal fluctuations.

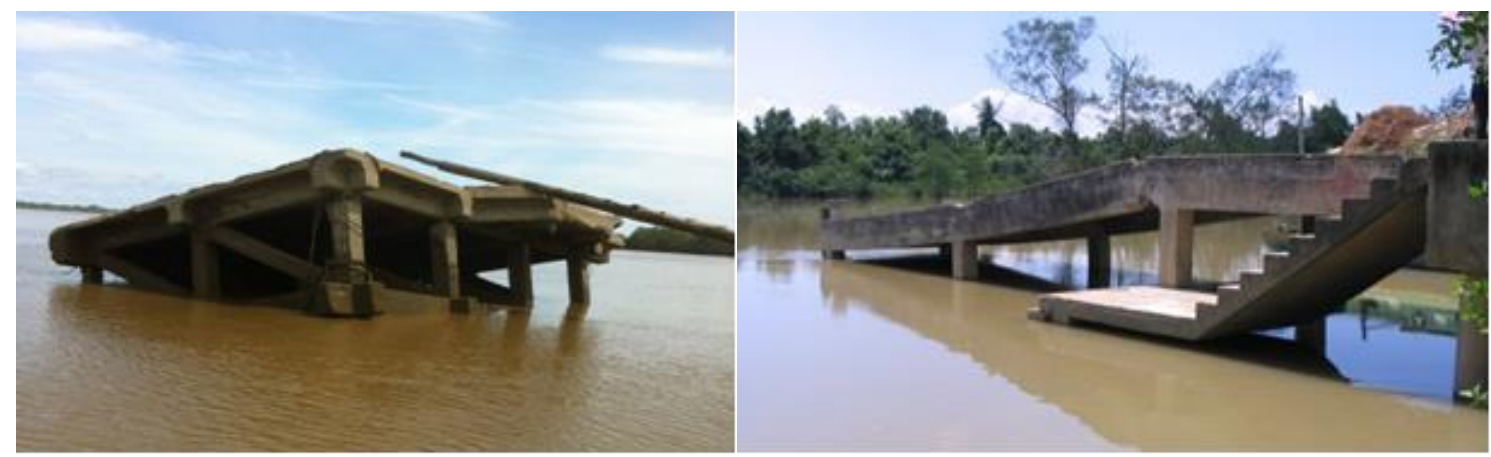

(a)

(b)

Figure 1 Failure of (a) wharf at the Lupar River and (b) jetty at Kpg. Hulu, Samarahan Division [1]-[2]

In the design of piles generally only the vertical load is considered and no provision is made for any lateral load. This practice could be due to the inexperience of the designers or the erroneous assumption that the river banks are stable. Despite the failures of several estuarine structures, there is a lack of research to formulate appropriate design guidelines. Therefore, a

This work was supported in part by Dana Principal Investigator, Universiti Malaysia Sarawak.

S.R. Kaniraj is with the Universiti Malaysia Sarawak, 94300 Kota Samarahan, Sarawak, Malaysia (phone: +6082583225, fax: +6082583410, e-mail: rkjshenbaga@feng.unimas.my).

L. J. Lee is with the Public Works Department, Kuching, Sarawak, Malaysia (e-mail: leelj@ sarawak.gov.my).

S.N.L. Taib is with the Universiti Malaysia Sarawak, 94300 Kota Samarahan, Sarawak, Malaysia (e-mail: tlinda@feng.unimasm.my). 
study has been undertaken to understand the influence of tidal fluctuation on the soil-pile interaction and to formulate improved approaches for the design of riverine and estuarine structures.

Table 1 Failures and distress in estuarine structures [1]-[2]

\begin{tabular}{|c|c|c|c|c|}
\hline $\begin{array}{l}\text { Sl. } \\
\text { No. }\end{array}$ & $\begin{array}{c}\text { Structure } \\
\text { and location }\end{array}$ & Soil conditions & Distress & Reasons \\
\hline 1 & $\begin{array}{l}\text { Wharf } \\
\text { Sg. Saribas, } \\
\text { Pusa }\end{array}$ & $\begin{array}{l}53 \mathrm{~m} \text { deep soft soil underlain by dense } \\
\text { sand; Undrained strength }\left(S_{u}\right) 20 \mathrm{kPa} \text { at the } \\
\text { top } 10 \mathrm{~m} \text {; From } 11 \text { to } 53 \mathrm{~m} S_{u} \text { increased to } \\
106 \mathrm{kPa}\end{array}$ & Collapse & $\begin{array}{l}\text { Large fluctuations in the river water } \\
\text { level and river bank erosion }\end{array}$ \\
\hline 2 & $\begin{array}{l}\text { Wharf } \\
\text { Batang } \\
\text { Lupar, } \\
\text { Lingga }\end{array}$ & $\begin{array}{l}\text { Top } 19.5 \mathrm{~m} \text { of soft clay; Standard } \\
\text { penetration test value } N<3 \text {; From } 19.5 \mathrm{~m} \\
\text { to } 57 \mathrm{~m} \text { of soft to hard clay; } 3<N<50 \text {. }\end{array}$ & Collapse & $\begin{array}{l}\text { Large fluctuations in the river water } \\
\text { level and river bank erosion }\end{array}$ \\
\hline 3 & $\begin{array}{l}\text { Jetty } \\
\text { Kpg. Hulu } \\
\text { Sebuyau }\end{array}$ & Unknown & $\begin{array}{l}\text { Structure } \\
\text { demolished due } \\
\text { to distress }\end{array}$ & Creep movement towards the river \\
\hline 4 & $\begin{array}{l}\text { Bridge } \\
\text { Sg. Palasan }\end{array}$ & $\begin{array}{l}S_{u}=15 \text { to } 25 \mathrm{kPa} \text { at the top } 10 \mathrm{~m} ; \text { From } 10 \\
\text { m to } 20 \mathrm{~m} 3<N<6 .\end{array}$ & Collapse & $\begin{array}{l}\text { Failure of the bridge pier due to } \\
\text { lateral soil movement }\end{array}$ \\
\hline 5 & $\begin{array}{l}\text { Bridge } \\
\text { Menyan, } \\
\text { Kanowit }\end{array}$ & $\begin{array}{l}\text { Top } 10 \text { to } 16 \text { m of very soft clay; Standard } \\
\text { penetration test resistance } N<3 ; 4.5 \text { to } 5.5 \\
\text { m thick stiff to hard clay }(10<N<50) \\
\text { layer below }\end{array}$ & Collapse & $\begin{array}{l}\text { Failure due to local scour at the } \\
\text { base of the pier }\end{array}$ \\
\hline 6 & $\begin{array}{l}\text { Wharf } \\
\text { Port Klang }\end{array}$ & $\begin{array}{l}\text { Top } 10 \mathrm{~m} \text { of soft clay; } N=0 . \text { From } 10 \mathrm{~m} \\
\text { to } 15 \mathrm{~m} N<5 \text {. }\end{array}$ & $\begin{array}{l}\text { Bearings plate } \\
\text { fell off }\end{array}$ & $\begin{array}{l}\text { Movement toward the sea side and } \\
\text { the joint between the access bridge } \\
\text { and the wharf opened up to } 120 \\
\mathrm{~mm}\end{array}$ \\
\hline
\end{tabular}

\section{LITERATURE REVIEW}

Depending upon how the lateral forces are induced a pile is designed as an active pile or passive pile [3]. In the case of an active pile, the superstructure causes a lateral load on the pile and the pile transmits the same to the stationary soil. The soil is the resisting medium. Passive piles, on the other hand, resist the forces due to the lateral soil movement along the length of pile. The situations that cause passive lateral loading on piles are: 1) Piles adjacent to embankments - the self-weight of the embankment causes the lateral movement of the foundation soil, particularly in soft soils; 2) Piles near tunneling and deep excavation operations - soil moves laterally due to the loss of lateral support; 3) Piles used for slope stabilization - unstable slopes and slopes in limiting equilibrium conditions tend to move laterally; 4) Dredging of riverbed or seabed - removal of material to increase the depth of water or mine the bed materials lowers riverbed level and leads to lateral movement of soil; 5) Scouring of river bed material - removal of bed material by the velocity of flow of water leads to instability of the superstructure; 6) Liquefaction induced lateral spreading of soil during earthquakes - lateral displacement of surficial soil due to liquefaction in soil layers below; and 7) Fluctuation of water level - the piezometric line fluctuates with tidal fluctuation affecting the stability of the riverbank slopes.

The methods of analysis and design of piles subjected to lateral forces range from very simple to relatively complicated numerical analysis. The authors have summarized the literature review on the analysis of various situations causing lateral loading on piles in [1] and [2]. The piles of the estuarine structures experience lateral forces as passive piles rather than as active piles. Of the seven situations mentioned before, the leading cause of lateral forces on the piles of estuarine structures is the fluctuation of water level. The fluctuation of water level could be considered to some extent as a rapid drawdown condition in the reservoirs. The literature concerning the effect drawdown on the stability of slopes is presented here.

Morgenstern [4] listed several failures of earth dams due to drawdown of reservoir water level. He reasoned that that the factor of safety of the earth slopes, shown in Fig. 2, would decrease if no dissipation of pore water pressure is assumed during drawdown. The factor of safety was affected by several parameters which included drawdown height $L$, steepness of slope $(n: 1)$, effective cohesion $c^{\prime}$, effective friction angle $\phi$ ', bulk unit weight $\gamma$, and height of slope $H$. Morgenstern assumed homogenous earth slope, horizontal flow lines and vertical equipotential lines. He developed a set of stability charts which showed the variation of the factor of safety for parametric variation: $n: 1=2: 1,3: 1,4: 1$, and $5: 1 ; c^{\prime} / \gamma H=0.0125,0.025$, and 0.05 ; drawdown ratio $L / H=0,0.25,0.5$, and $\phi^{\prime}=20^{\circ}, 30^{\circ}$, and $40^{\circ} . L / H=0$ and 1 correspond to no drawdown and complete drawdown, respectively. As an example of the effect of drawdown on factor of safety, for $c^{\prime} / \gamma H=0.0125$ and $\phi^{\prime}=30^{\circ}$ the factor of safety for no draw down is 1.6 and decreases to 0.67 for complete drawdown.

Nearly four decades later, Lane and Griffiths [5] investigated the effect drawdown on the stability of slopes using finite element analysis. They developed charts for factor of safety similar to those of Morgenstern's charts. Lane and Griffith distinguished two different types of drawdown, namely slow drawdown and rapid drawdown. Slow drawdown or partial 
submergence is the situation where the free surface in the soil slope has stabilized to the new reservoir level. This situation occurs when the water level in the reservoir is lowered very slowly and the soil is sufficiently permeable to dissipate the pore water pressure quickly. Rapid drawdown is the situation where the free surface in the soil slope is horizontal and remains at the same level prior to drawdown of the reservoir level. The conditions that prevail in the banks at estuaries - daily tidal fluctuation and low permeability soils - are close to the rapid drawdown situation. The results of Lane and Griffiths' analysis were similar to the results of Morgenstern. As an example of the effect of drawdown on factor of safety, for $c^{\prime} / \gamma H=0.05$ and $\phi^{\prime}=20^{\circ}$ the factor of safety for $1: 2$ slope for no draw down is 1.84 . The factor of safety decreases to 1.2 at $L / H=0.3$, to 1 at $L / H=0.5$, and to 0.8 at complete drawdown.

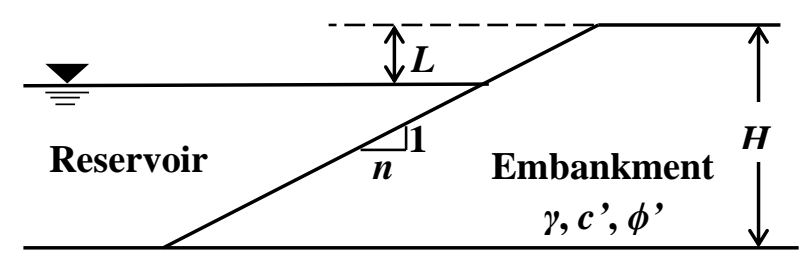

\section{Foundation soil}

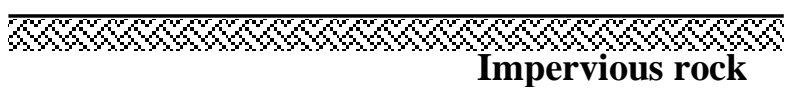

Figure 2 Drawdown of water level in reservoir

Zheng et al. [6] studied the influence of the fluctuation of water level on the stability of a vertical slope. The vertical slope is a particular case of earth slopes often encountered in deep excavation. Zheng et al. performed numerical analysis of the vertical slope using the commercial computer program of the Geo-slope International Ltd. They used the SEEP/W program to construct the slope model and to predict soil water content and pore water pressure. Two other computer programs, namely SIGMA/W and SLOPE/W, were also used in the analysis. SLOPE/W uses limit equilibrium method for slope stability analysis. Two types of drawdown were considered, rapid drawdown $(1 \mathrm{~m} / \mathrm{h})$ and slow drawdown $(0.05 \mathrm{~m} / \mathrm{h})$. Zheng et al. concluded that the influences of rapid and slow drawdown on factor of safety are significantly different. Under slow drawdown condition, the factor of safety decreases to a minimum value at any given elevation of drawdown level $(0<L / H<$ 1) and then the factor of safety increases. However, in the case of rapid drawdown, the factor of safety will continue to decrease as the water level decreases and it will reach a minimum value at complete drawdown $(L / H=1)$. The results of Zheng et al.'s study were in agreement with those of Lane and Griffith [5].

In their study [7] considered a $16.2 \mathrm{~m}$ high earth dam on $9.2 \mathrm{~m}$ thick foundation soil. The dam had a central impervious core and both the side slopes were $19^{\circ}$. By coupling SEEP/W with SLOPE/W, they investigated the effects of drawdown rate, saturated hydraulic conductivity and unsaturated shear strength of dam materials on the stability of the upstream slope of an earth dam. They considered four drawdown rates $-0.5 \mathrm{~m} / \mathrm{day}, 2 \mathrm{~m} / \mathrm{day}, 6 \mathrm{~m} / \mathrm{day}$, and $8 \mathrm{~m} /$ day - in the analysis. From the results, [7] reached conclusions similar to those of [5] and [6]. Drawdown decreased the stability of the upstream slope. Lower drawdown rates resulted in higher safety factors. The slope was more stable during drawdown if constructed with highly permeable soil $\left(k=3 \times 10^{-3} \mathrm{~m} / \mathrm{s}\right)$ than with low permeable soil $\left(k=3 \times 10^{-7} \mathrm{~m} / \mathrm{s}\right)$. In general, the lowest safety factor was found to be at about one-third of the reservoir water level $(L / H=2 / 3)$.

The past studies have established the effect of water level fluctuation on the stability of earth slopes. However, no information is available regarding the extent of associated lateral movement of soil and the lateral forces that might be induced on piles as a result of the lateral movement.

\section{STABILITY ANALYSIS AND FIELD INSTRUMENTATION}

A bridge site at Pusa and a jetty site at Lupar River in Seduku have been chosen for instrumentation. At both sites, the soil profile consists of deep soft silty clay and there is 4 to $7 \mathrm{~m}$ tidal fluctuation. A reinforced concrete bridge across the Rimbas River shown in Fig. 3 is to be constructed at the Pusa site. Abutments Ab-A and Ab-B and piers P1, P2, P6 and P7 will be supported on $1 \mathrm{~m}$ diameter bored concrete piles and the estimated active pile length is $62 \mathrm{~m}$. Piers P3, P4 and P5 will be supported on $1.2 \mathrm{~m}$ diameter steel pipe piles with the same active pile length of $62 \mathrm{~m}$. The soil profile at the site is shown in Fig, 4. A reinforced concrete passenger jetty shown in Fig. 5 is to be constructed at the Seduku site. The jetty will be supported on $350 \mathrm{~mm}$ diameter spun piles with active length of about $42 \mathrm{~m}$.

Undrained analysis for the factor of safety of the riverbanks was carried out using Morgenstern-Price limit equilibrium method in the SLOPE/W computer program. The results of the analysis are summarized in Table 2 . The results show the adverse effect of drawdown on the stability of slopes. During low tide the factor of safety decreases to unstable limiting state. However, as the low tide level exists for less than an hour, the riverbank slope does not fail or collapse completely. However, due to repetitive cycles of high and low tides the river bank may tend to creep slowly towards the river 


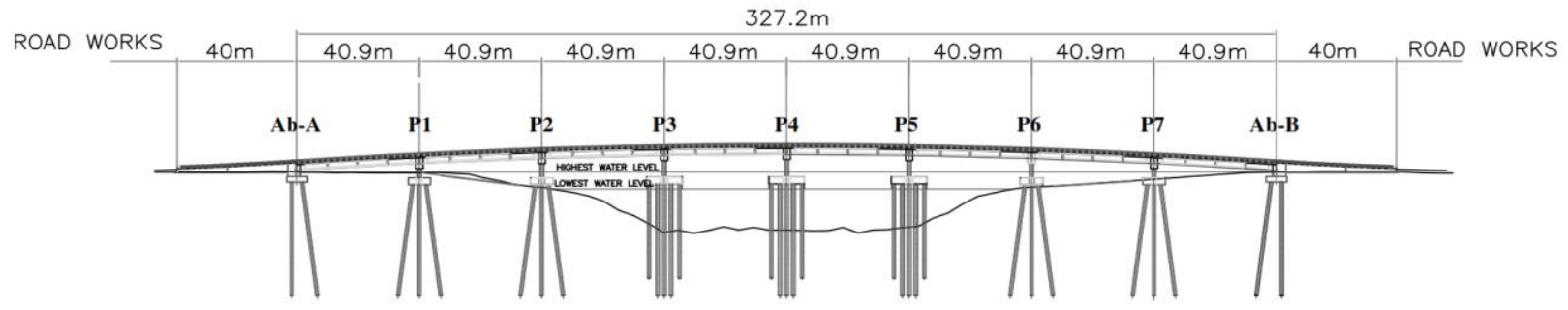

Figure 3 Elevation of the bridge at Pusa - western bank on the left [8]

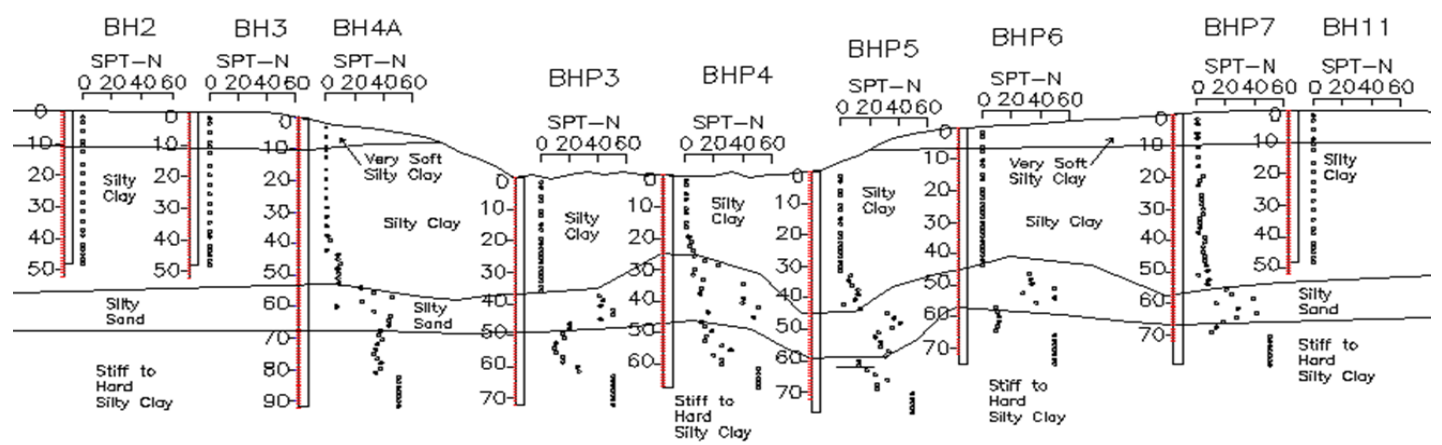

Figure 4 Soil profile at the bridge site at Pusa- western bank on the left [8]

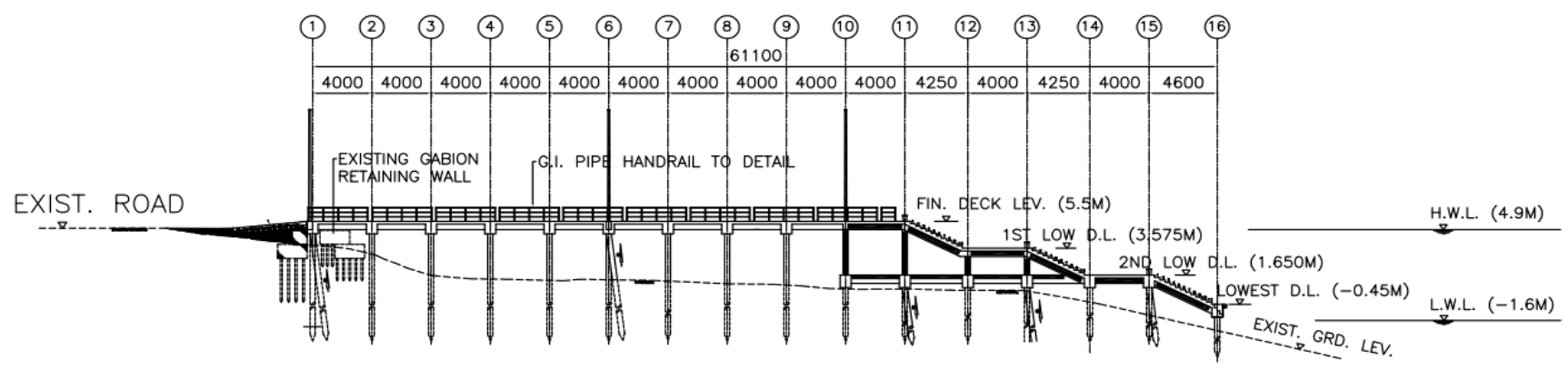

Figure 5 Elevation of the Seduku jetty [8]

Table 2 River water level and factor of safety

\begin{tabular}{lcccc}
\hline \multirow{2}{*}{ Riverbank } & \multicolumn{2}{c}{ River water level, $\mathrm{m}$} & \multicolumn{2}{c}{ Factor of safety } \\
\cline { 2 - 5 } & High tide & Low tide & High tide & Low tide \\
\hline Pusa - Eastern bank & 100 & 93 & 1.805 & 1.084 \\
Pusa - Western bank & 100 & 93 & 2.195 & 1.057 \\
Seduku & 158 & 152 & 1.958 & 1.088 \\
\hline
\end{tabular}

Table 3 Details of the instrumentation at the Pusa and Seduku sites

\begin{tabular}{|c|c|c|c|c|}
\hline Site & Location & Instrumentation & Designation & Details \\
\hline \multirow{3}{*}{$\begin{array}{l}\text { Pusa - } \\
\text { Eastern } \\
\text { bank }\end{array}$} & \multirow{3}{*}{$\begin{array}{l}\text { Near BH4A } \\
\text { (Fig. 4) }\end{array}$} & Inclinometer & PINC1 & $\begin{array}{l}\text { To } 52 \mathrm{~m} \text { below the } \\
\text { ground surface inside soil }\end{array}$ \\
\hline & & \multirow{2}{*}{ Piezometer } & P1 & At $5 \mathrm{~m}$ depth \\
\hline & & & P2 & At $10 \mathrm{~m}$ depth \\
\hline \multirow{3}{*}{$\begin{array}{l}\text { Pusa - } \\
\text { Western } \\
\text { bank }\end{array}$} & \multirow{3}{*}{$\begin{array}{l}\text { Near BHP7 } \\
\text { (Fig. 4) }\end{array}$} & Inclinometer & PINC2 & $\begin{array}{l}\text { To } 75 \mathrm{~m} \text { below the } \\
\text { ground surface inside soil }\end{array}$ \\
\hline & & \multirow{2}{*}{ Piezometer } & P3 & At $6.5 \mathrm{~m}$ depth \\
\hline & & & $\mathrm{P} 4$ & At $12 \mathrm{~m} \mathrm{depth}$ \\
\hline $\begin{array}{l}\text { Pusa - } \\
\text { River bed }\end{array}$ & $\begin{array}{l}\text { In between } \\
\text { BH4A and } \\
\text { BHP3 } \\
\text { (Fig. 4) }\end{array}$ & Piezometer & P5 & On the river slop \\
\hline Seduku & $\begin{array}{l}\text { Grid line } 11 \\
\quad \text { (Fig. 5) }\end{array}$ & Inclinometer & SINC1 & $\begin{array}{l}\text { Total length of the } \\
\text { inclinometer inside the } \\
\text { slab-pile cap-pile } \approx 48 \mathrm{~m}\end{array}$ \\
\hline
\end{tabular}




\section{UNIMAS e-Journal of Civil Engineering}

Two inclinometer casings were installed in the soil at the Pusa site and one inclinometer casings was installed inside the pile at the Seduku site. In addition five vibrating wire piezometers were installed at the Pusa site. The details of the instrumentation at the two sites are shown in Table 3.

\section{RESULTS OF FIELD MEASUREMENTS AND DISCUSSIONS}

Figure 6 shows the inclinometer readings at different water levels for inclinometers PINC1 and SINC1. Similar trends of readings were recorded for inclinometer PINC2 also. Maximum lateral movement recorded by the inclinometers for selected water levels are shown in Table 4. Zero lateral movement indicates the beginning of inclinometer observations from the first high tide water level.

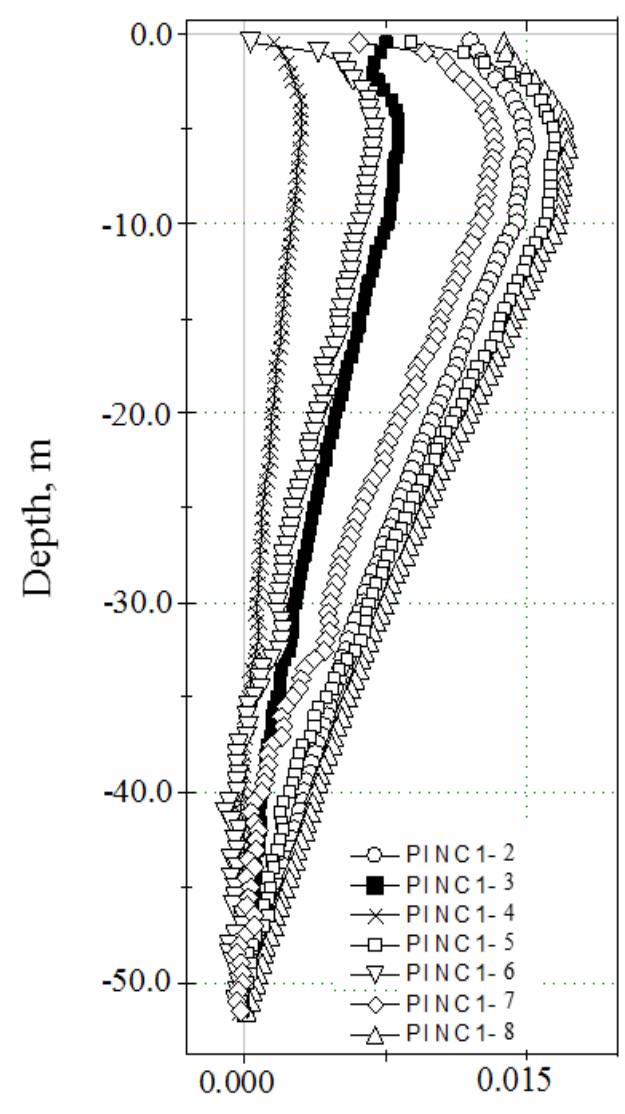

Cumulative displacement, $m$

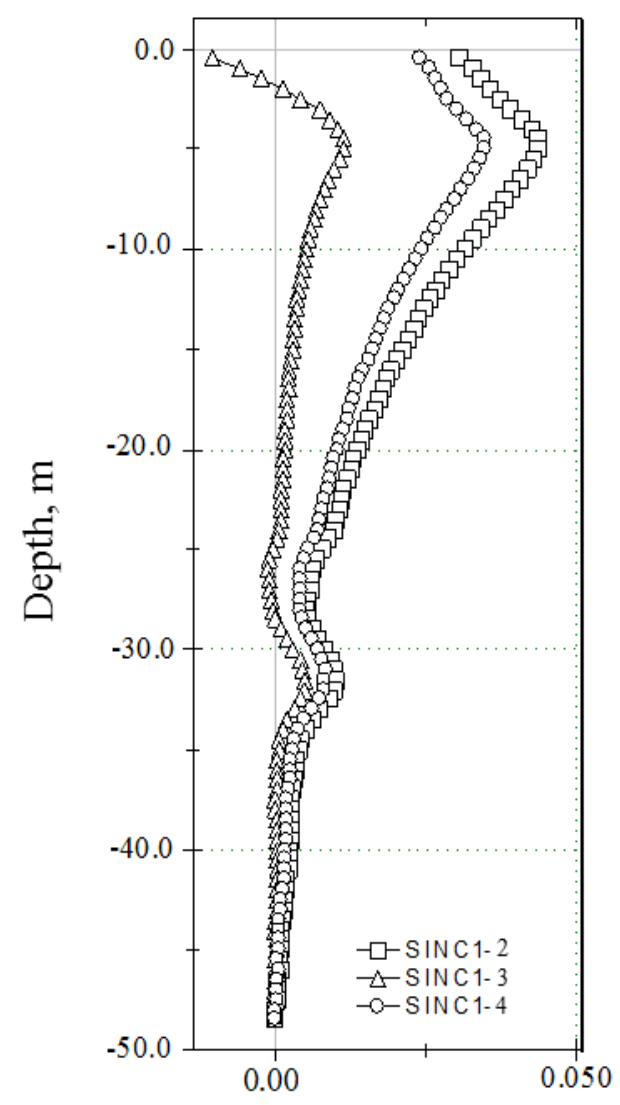

Cumulative displacement, $\mathrm{m}$

Figure 6 Inclinometer readings for PINC1 and SINC1 [8]

Table 4 Maximum lateral movement of inclinometers [8]

\begin{tabular}{cccc}
\hline Reading & Date and Time & $\begin{array}{c}\text { Water level } \\
\text { (RL in } \mathrm{m})\end{array}$ & $\begin{array}{c}\text { Lateral movement } \\
(\mathrm{mm})\end{array}$ \\
\hline PINC1-1 & $15 / 11 / 2012,18: 09$ & 10.57 & 0.00 \\
PINC1-2 & $15 / 11 / 2012,14: 06$ & 5.53 & 14.90 \\
PINC1-3 & $13 / 12 / 2012,14: 25$ & 7.68 & 8.20 \\
PINC1-4 & $13 / 12 / 2012,16: 00$ & 9.62 & 3.00 \\
PINC1-5 & $01 / 02 / 2013,15: 01$ & 4.88 & 16.40 \\
& & & \\
PINC2-1 & $31 / 01 / 2013,08: 16$ & 9.79 & 0.00 \\
PINC2-2 & $31 / 01 / 2013,14: 12$ & 4.63 & 13.90 \\
PINC2-3 & $01 / 02 / 2013,08: 57$ & 9.68 & 1.80 \\
PINC2-4 & $30 / 05 / 2013,10: 47$ & 9.91 & 5.20 \\
& & & \\
SINC1-1 & $14 / 04 / 2013,09: 21$ & 7.41 & 0.00 \\
SINC1-2 & $17 / 05 / 2013,15: 59$ & 2.96 & 34.70 \\
SINC1-3 & $18 / 05 / 2013,11: 33$ & 6.92 & 11.40 \\
SINC1-4 & $28 / 05 / 2013,15: 56$ & 2.12 & 43.60 \\
\hline
\end{tabular}


All the piezometers showed similar trends of movements and the effect of tidal fluctuation on lateral movement. The soil and the pile moved towards the river during low tide and they moved back to their initial locations. The maximum lateral movement occurred near the top at about $5 \mathrm{~m}$ below the ground surface and the lateral movement decreased with increase in depth. Figure 7 shows the variation of maximum lateral movement of the inclinometers with water level for PINC1. There was no uniform trend in the variation of maximum lateral movement with water level. There was a residual lateral movement at all points and there was a creep like tendency with increase in time and cycles of tidal fluctuation. The average rate of residual lateral movement near the top of PINC2 was around $1 \mathrm{~mm}$ per month.

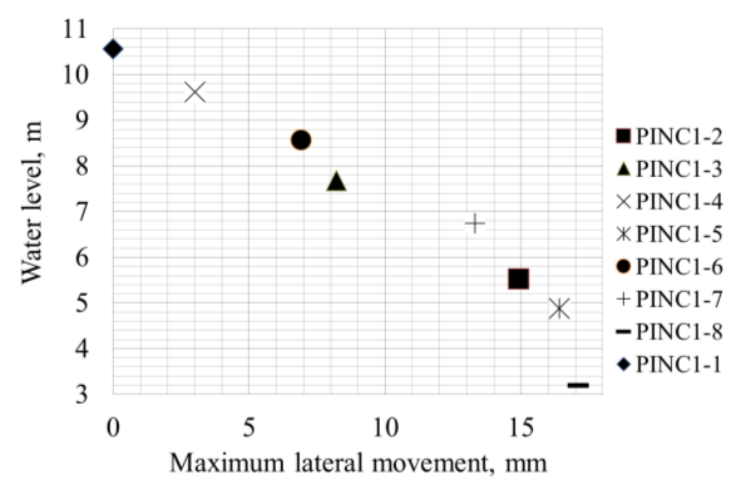

Figure 7 Variation of maximum lateral movement with water level for PINC1 [8]

Figures 8 shows the readings of piezometers P1, P2, and P5 recorded during 14-22 January 2013. 14-17 January 2013 were the king tide duration. The rest of the period was normal tide duration
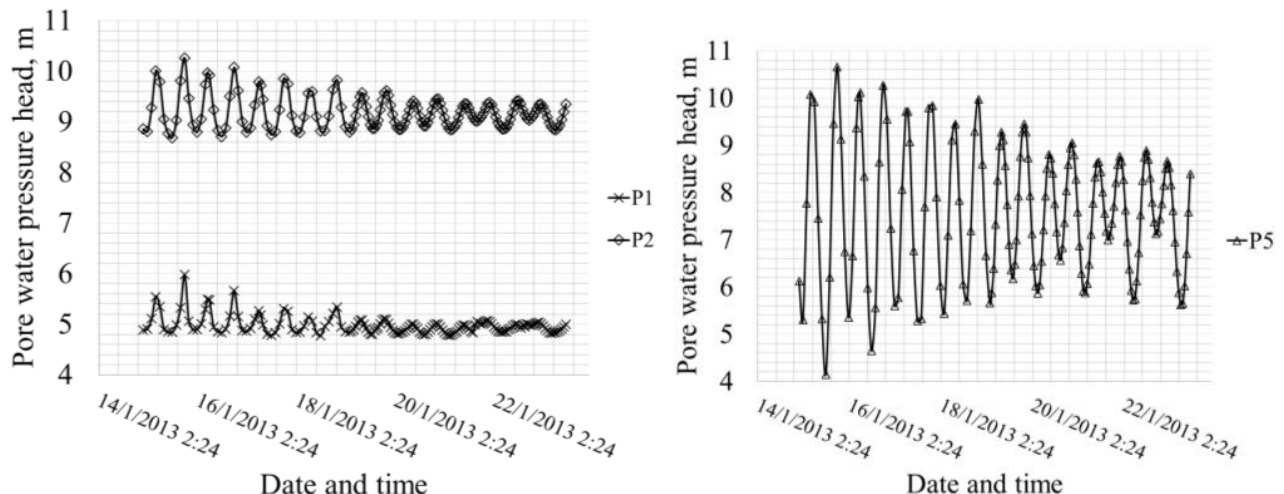

Figure 8 Piezometer readings for P1 and P5 [8]

When the water level fluctuated around $3 \mathrm{~m}$, the pore water pressure in piezometer P1 was in the range of 48 to $50 \mathrm{kPa}$ (Fig. 8). But, the behaviour was different when the tidal fluctuation was more than $5 \mathrm{~m}$. The pore water pressure remained at $48 \mathrm{kPa}$ when the water level decreased to RL $4 \mathrm{~m}$ (about $1 \mathrm{~m}$ below the RL of P1). When the water level increased to RL $10.6 \mathrm{~m}$, pore water pressure in $\mathrm{P} 1$ was about $60 \mathrm{kPa}$. It was perhaps due to reasons of the low permeability of the soil and the short duration of only about 6 hours between the low and high tides that the pore water pressure did not dissipate quickly when the water level went down and also did not build up quickly as the water level went up. The trend of variation of pore water pressure in P2, P3 and P4 was similar to that at P1. The details of the variation of pore water pressure in P2, P3 and P4 are presented in [8].

\section{FUTURE RESEARCH}

The monitoring of the instrumentation is being continued. Efforts are on to install an inclinometer in the soil at the Seduku site and also at other project sites where there is tidal fluctuation. An analytical model that will simulate the lateral movement of observed at the sites has been formulated. Preliminary analysis using PLAXIS finite element computer program has been carried out. Based on the preliminary results, additional soil data are being obtained. The data from the present and next phases of research will be used to calibrate the model. After developing a realistic model successfully, parametric studies will be carried out and to design guidelines will be formulated. 


\section{UNIMAS e-Journal of Civil Engineering}

\section{CONCLUSIONS}

The following conclusions made from the study presented in the paper.

1. Literature review reveals the influence of drawdown of water on the stability of earth slopes. Rapid drawdown is more critical than slow drawdown.

2. Factors of safety of the riverbanks at the Pusa bridge site and Seduku jetty site were determined by limit equilibrium slope stability analysis in the SLOPE/W computer program. The results showed that the factors of safety were affected by tidal fluctuation. The factor of safety in all cases decreased from 1.8 to 2 at high tide to close to limiting equilibrium conditions of 1 at low tide.

3. Inclinometers installed at the Pusa bridge site in the soil and in a pile at the Seduku jetty site recorded lateral movement towards the river during low tide and in the opposite direction during high tide. The lateral movement was the maximum at about $5 \mathrm{~m}$ below the ground surface. Build-up of residual lateral movement was also observed during repetitive cycles of tidal fluctuation.

4. Piezometers readings at the Pusa bridge site showed that the pore water pressure did not dissipate quickly when the water level went down and also did not build up quickly as the water level went up.

\section{ACKNOWLEDGMENT}

Thanks are due to the Research and Innovation Management Centre of the Universiti Malaysia Sarawak for the Dana Principal Investigator research grant. The support of the PWD Sarawak for the installation of instrumentation at the sites is acknowledged. The second author thanks PWD Sarawak for granting study leave and financial support.

Use the singular heading even if you have many acknowledgments. Sponsor and financial support acknowledgments should be placed in the unnumbered footnote on the first page.

\section{REFERENCES}

[1] L. J. Lee, S. R. Kaniraj, and S. N. L. Taib, "Lateral instability of piled riverine structures in the estuaries of Sarawak," in Proc. Soft Soils Engineering Int. Conf., Kuching, 2013.

[2] L. J. Lee, S. R. Kaniraj, and S. N. L. Taib, "Monitoring the ground movement and pore water pressure at the banks of estuaries due to tidal fluctuation," in Proc. Geotechnics for Sustainable Development - Geotec Hanoi 2013, Hanoi, 2013.

[3] E. E. De beer, "Piles subjected to static lateral loads," in Proc. 9th Int. Conf. Soil Mechanics and Foundation Engineering, Specialty Session 10, Tokyo, 1997, pp. 1-14

[4] N. Morgenstern, "Stability charts for earth slopes during rapid drawdown," Geotechnique, vol. 13, June 1963, pp. 121-131.

[5] P. A. Lane and D. V. Griffiths. "Assessment of stability of slopes under drawdown conditions," J. Geotechnical and Geoenvironmental Eng., vol. 126, May 2000, pp. 443-450.

[6] Z. Zheng, L. Hou, and C. Wu, "Stability of slope which locates on reservoir region and the corresponding influence mechanisms induced by fluctuation of water level," in Proc. Multimedia Technology (ICMT) Int. Conf., Hangzhou, 2011, pp. 4591-4595.

[7] T. Souliyavong, C. Gallage, P. Egodawatta, and B. Maher, "Factors affecting the stability analysis of earth dam slopes subjected to reservoir drawdown," in Proc. 2nd Int. Conf. Geotechnique, Construction Materials and Environment, Kuala Lumpur, 2012

[8] L. J. Lee, S. R. Kaniraj, and S. N. L. Taib, "Effect of tidal fluctuation on ground movement and pore water pressure," in Proc. Tunneling and Underground Construction, GeoShanghai 2014, Geotechnical Special Publications 242, ASCE, 2014, pp.35-44. 